\title{
Fasilitas MCK Di Ruang Publik Untuk Keperluan Warga Sekitar Dan Wisatawan
}

\author{
Erik Saut H Hutahaean ${ }^{1}$, Dhian Tyas Untari ${ }^{2}$, Soehardi ${ }^{2}$, Tulus Sukreni ${ }^{3}$, \\ Timorora Sandha Perdhana ${ }^{1}$, Fata Nidaul Khasanah ${ }^{4, *}$, Iskandar Zulkarnaen ${ }^{3}$, Djuni \\ Thamrin $^{2}$ \\ ${ }^{1}$ Fakultas Psikologi; Universitas Bhayangkara Jakarta Raya; Jl. Raya Perjuangan No. 81, \\ Marga Mulya, Bekasi Utara, Kota Bekasi, Jawa Barat 17121, Telp: (021) 88955882, \\ 889955883; e-mail: erik.saut@dsn.ubharajaya.ac.id, timorora.sandha@dsn.ubharajaya.ac.id \\ ${ }^{2}$ Fakultas Ekonomi dan Bisnis; Universitas Bhayangkara Jakarta Raya; Jl. Raya Perjuangan \\ No. 81, Marga Mulya, Bekasi Utara, Kota Bekasi, Jawa Barat 17121, Telp: (021) 88955882, \\ 889955883; e-mail: dhian.tyas@dsn.ubharajaya.ac.id, soehardi@dsn.ubharajaya.ac.id, \\ djunithamrin@dsn.ubharajaya.ac.id \\ ${ }^{3}$ Fakultas Teknik; Universitas Bhayangkara Jakarta Raya; Jl. Raya Perjuangan No. 81, Marga \\ Mulya, Bekasi Utara, Kota Bekasi, Jawa Barat 17121, Telp: (021) 88955882, 889955883; e- \\ mail: tulus.sukreni@dsn.ubharajaya.ac.id, iskandar.zulkarnaen@dsn.ubharajaya.ac.id \\ ${ }^{4}$ Fakultas IImu Komputer; Universitas Bhayangkara Jakarta Raya; Jl. Raya Perjuangan No. 81, \\ Marga Mulya, Bekasi Utara, Kota Bekasi, Jawa Barat 17121, Telp: (021) 88955882, \\ 889955883; e-mail: fatanidaul@gmail.com \\ * Korespondensi: e-mail: fatanidaul@gmail.com
}

\begin{abstract}
Muara Gembong district is often the attention of the surrounding community, especially the people of Jakarta and Bekasi. Its location directly facing the sea makes this sub-district often visited by various parties for travel or for other activities such as mangrove planting. There is one small problem but it is often considered as a very important thing related to the pattern of life of the community and also supporting infrastructure to lift tourism potential. One of the important is the availability of infrastructure that can be used by residents for bathing, washing and toilet purposes. Likewise for tourists, because it requires the infrastructure available. The results of discussions, interviews and field observations get there are three points that are quite ahagia ative to be able to overcome existing problems. Through the construction of MCK / Toilet infrastructure for the community and tourists are expected to have an impact related to efforts to lift the potential of tourism in muara gembong subdistrict. MCK / toilet development program also has an impact on the formation of healthy lifestyle patterns, and minimize environmental pollution whose source comes from human wastewater. The benefits of the program require continuous action from the community. Such as in the form of a cleanliness management system and its care.
\end{abstract}

Keywords: MCK/Toilet, Muara Gembong, Infrastructure, Tourism Potential

\begin{abstract}
Abstrak
Kecamatan Muara Gembong kerap menjadi perhatian masyarakat sekitarnya, khususnya masyarakat Jakarta dan Bekasi. Letaknya yang langsung menghadap kearah laut membuat kecamatan ini kerap dikunjungi oleh berbagai pihak untuk berwisata ataupun untuk kegiatan lainnya seperti penanaman mangrove. Terdapat satu permasalahan kecil tetapi sering dianggap sebagai hal yang sangat penting terkait dengan pola kehidupan masarakatnya dan juga prasarana pendukung untuk mengangkat potensi wisata. Salah satu yang penting adalah ketersediaan prasarana yang dapat digunakan warga untuk keperluan mandi, cuci dan kakus. Begitupun juga bagi wisatawan, karena memerlukan tersedia prasarana tersebut. Hasil diskusi,
\end{abstract}


wawancara dan observasi lapangan mendapatkan ada tiga titik yang cukup untuk dapat mengatasi permasalahan yang ada. Melalui pembangunan prasarana MCK/Toilet bagi masyarakat dan wisatawan diharapkan dapat memberikan dampak yang berikaitan dengan upaya mengangkat potensi pariwisata yang ada di lingkungan Kecamatan Muara Gembong. Program pembangunan MCK/toilet juga berdampak kepada terbentuknya pola perilaku hidup yang sehat, dan meminimalkan pencemaran lingkungan yang sumbernya berasal dari air limbah manusia. Manfaat program memerlukan adanya tindakan yang berkesinambungan dari masyarakat. Seperti misalnya berupa sistem pengelolaan kebersihannya dan perawatannya.

Kata kunci: MCK/Toilet, Muara Gembong, Prasarana, Potensi Wisata

\section{Pendahuluan}

Muara Gembong adalah salah satu bagian dari sisitem Kepemerintahan Kabupaten Bekasi, dari sekitar 23 kecamatan yang ada Muara Gembong memiliki wilayah yang paling luas dibandingkan dengan kecamatan yang lainnya. Karakteristik wilayah sangat didominasi dengan wilayah perairan laut. Secara geografis berada pada bagian terluar (ujung), dan terletak diantara Laut Jawa, Teluk Jakarta, dan juga menjadi muara dari aliran sungai Citarum. Berdasarkan data dari BPS (Biro Pusat Statistik Kabupaten Bekasi) tercatat memiliki luas wilayah 140, 09 ( km2/sq.km) dan yang diisi oleh sekitar 40 ribuan penduduk (BPS Kabupaten Bekasi, 2020). Sebagian besar penduduknya mengandalkan sektor kelautan dan perikanan sebagai mata pencahariannya, dan tidak memiliki penghasilan yang tetap. Sehingga selain mengandalkan hasil nelayan, penduduknya juga mengandalkan hasil tambak (Deswati \& Luhur, 2014) dan beberapa juga ada yang pertanian.

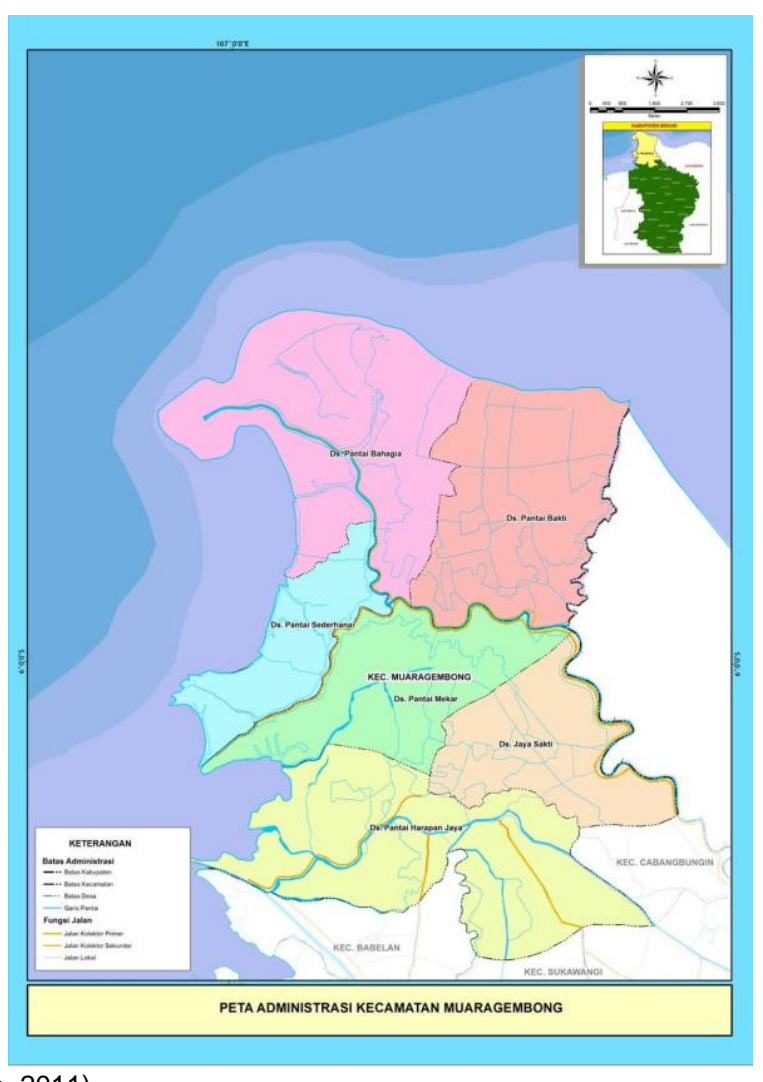

Sumber: (Asyiawati \& Akliyah, 2011)

Gambar 1. Peta Wilayah Muara Gembong 
Karakteristik geografis Kecamatan Muara Gembong sangat memungkinkan Sebagian wilayanya dapat terendam oleh air laut (Daniswara, 2021). Dampaknya adalah membuat pertanian akibat terendam air laut yang bersifat asin sehingga berkurangnya lahan tanam. Saat air laut meningkat berdampak kepada permukiman menjadi tidak dapat dihuni karena air laut menggenangi rumah warga. Fasilitas umum yang ada seperti jalan, lapangan, dan sekolah di kawasan juga mengalami kerusakan akibat terendam air laut terus menerus. Kebutuhan air juga mengalami kendala, karena air tanah pada kawasan pantai Bahagia menjadi tercemar air laut. Akibatnya air tidak dapat digunakan untuk pemakaian rumah tangga (Daniswara, 2021). Misalnya untuk keperluan mandi, cuci dan kakus (MCK). Berdasarkan wawancara dan pengamatan dapat diketahui masih ditemukan ada warga yang belum memiliki fasilitas MCK di dalam rumahnya. Selain dengan membeli air bersih, kebanyakan dari warga sangat mengandalkan aliran sungai Citarum untuk dapat memenuhi kebutuhan MCK, meskipun kualitas airnya sangat keruh. Belum lagi tingkat cemaran yang terkandung pada air sungai Citarum.

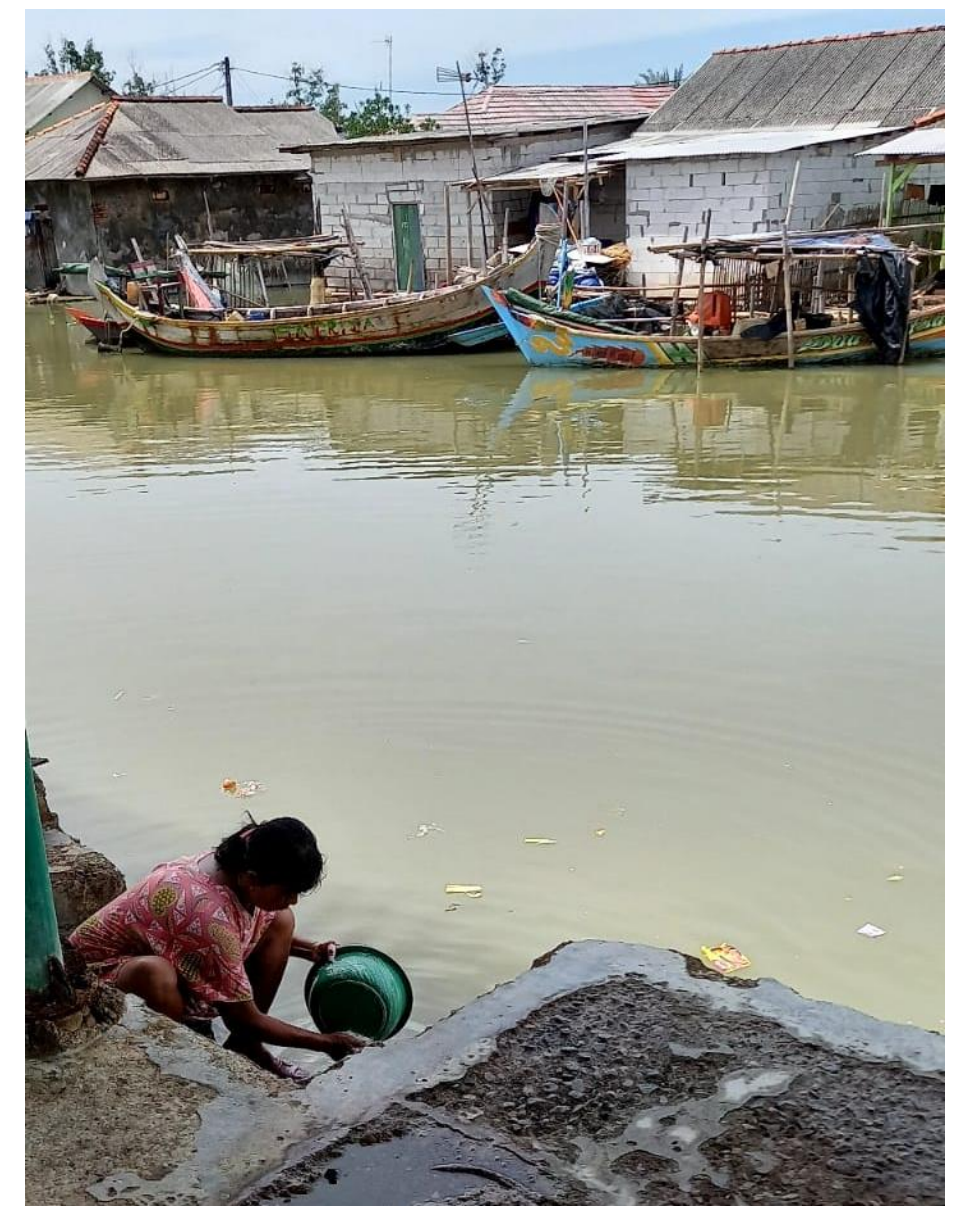

Sumber: Hasil Pelaksanaan (2021)

Gambar 2. Kondisi Air Aliran Citarum, Muara Gembong

Kecamatan Muara Gembong juga memiliki potensi sebagai daerah wisata bahari, dari sejumlah potensi wisata (Jabarprov.go.id, 2017) yang ada menjadi alasan banyak orang datang untuk berwisata di akhir pekan. Hal ini turut mendatangkan permasalahan bagi Kecamatan dan 
Warga khususnya dalam menyediakan sarana MCK kepada wisatawan. Khususnya terkait dengan tidak tersedianya toilet yang dapat digunakan oleh publik. Keadaan ini sangat berpotensi dalam memunculkan masalah baru lainnya bagi masyarakat. Penelitian mengungkap bahwa ketersediaan toilet menjadi salah satu bagian penting dari aspek kepuasan pada wisatawan (Susetyarini \& Jussac Maulana, 2011) dan juga menjadi salah satu bagian dari daya tarik wisata (Widyanti et al., 2020). Penelitian lainnya mengungkap bahwa keberhasilan pengelolaan lokasi wisata adalah tersedianya prasarana seperti salah satunya adalah MCK (Alfiah et al., 2020). Berdasarkan pengamatan di lapangan, didapatkan ada sarana MCK yang sangat rusak dan juga sudah sangat tidak layak. Berdasarkan kondisi lapangan, tim kegiatan pembangunan sarana MCK yang dapat dimanfaatkan bagi masyarakat dan wisatawan.

\section{Metode Pelaksanaan}

\subsection{Koordinasi Pelaksanaan}

Tim pelaksana Abdimas dari Universitas Bhayangkara Jakarta Raya (UBJ) melakukan koordinasi dengan pihak aparatur tempat pelaksanaan program Abdimas. Tim abdimas UBJ berkoordinasi dengan pihak Kecamatan Muara Gembong dan Kepolisian Sektor Muara Gembong. Koordinasi dilaksanakan sebagai salah satu langkah pelaksanaan yang bertujuan untuk menjelaskan maksud kedatangan dan rencana kegiatan. Adapun Koordinasi dilakukan dalam rangka menjalin proses kerja dengan pihak-pihak terkait dalam rangka melaksanakan program kegiatan yang terkait dengan upaya meningkatkan potensi pariwisata di Kecamatan Muara Gembong.

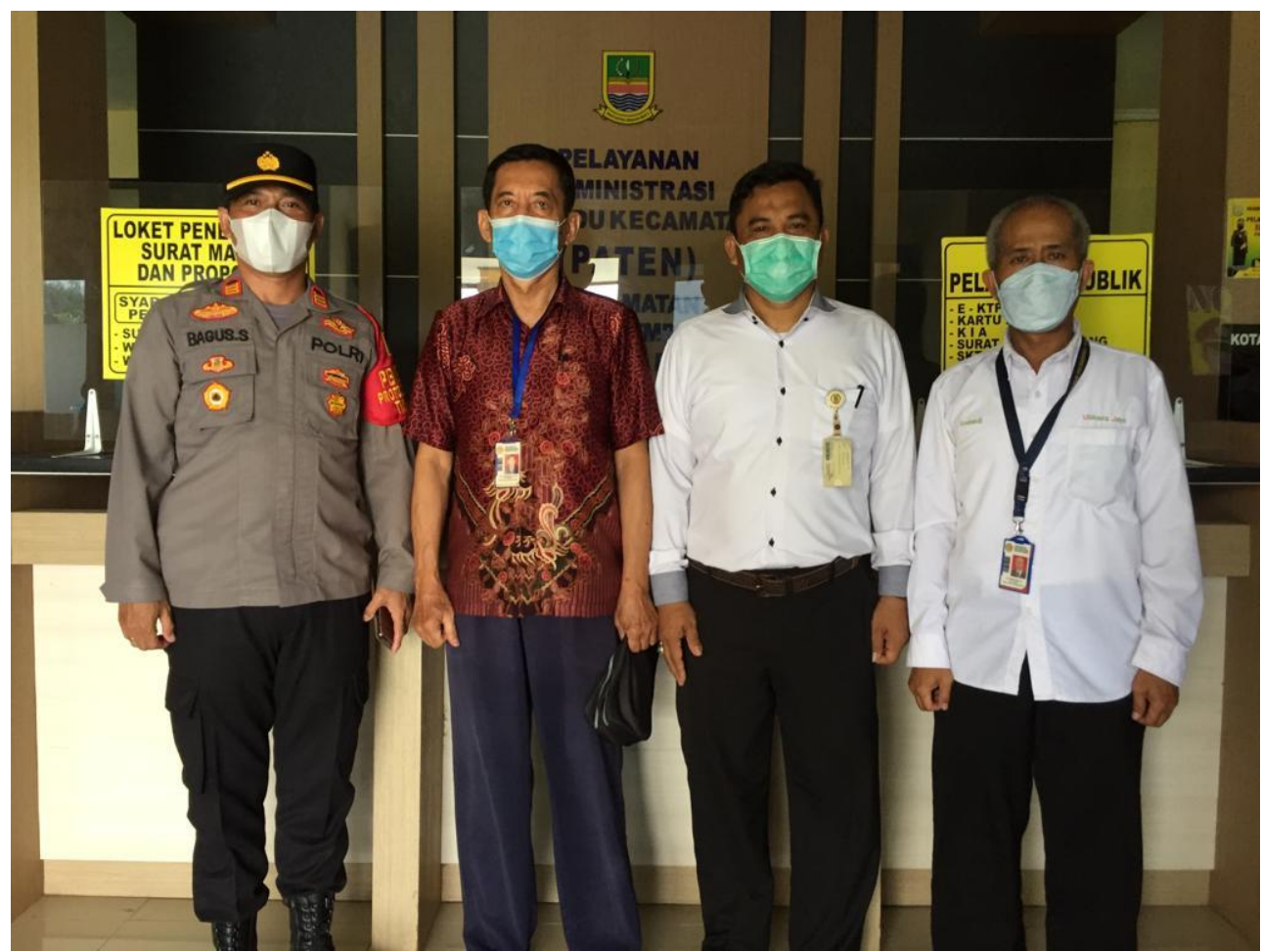

Sumber: Hasil Pelaksanaan (2021)

Gambar 3. Foto Kegiatan Koordinasi 


\subsection{Survey Lokasi}

Kegiatan ini dilaksanakan dengan mengunjungi lokasi abdimas, khususnya wilayah sekitaran lokasi abdimas. Survey dilakukan untuk mendapatkan gambaran nyata terhadap prasarana pendukung yang biasanya dimanfaatkan untuk masyarakat dan wisatawan yang berkunjung. Fakta yang dikumpulkan kemudian diolah dan dianalisis untuk menyimpulkan gambaran nyata yang relevan dengan program abdimas yang akan dilaksanakan, yaitu program mengenai Sadar Wisata, metode survey dilakukan dengan proses observasi dan wawancara terhadap pihak instansi pemerintah kecamatan, masyarakat penggiat pariwisata, dan kelompok masyarakat umum.
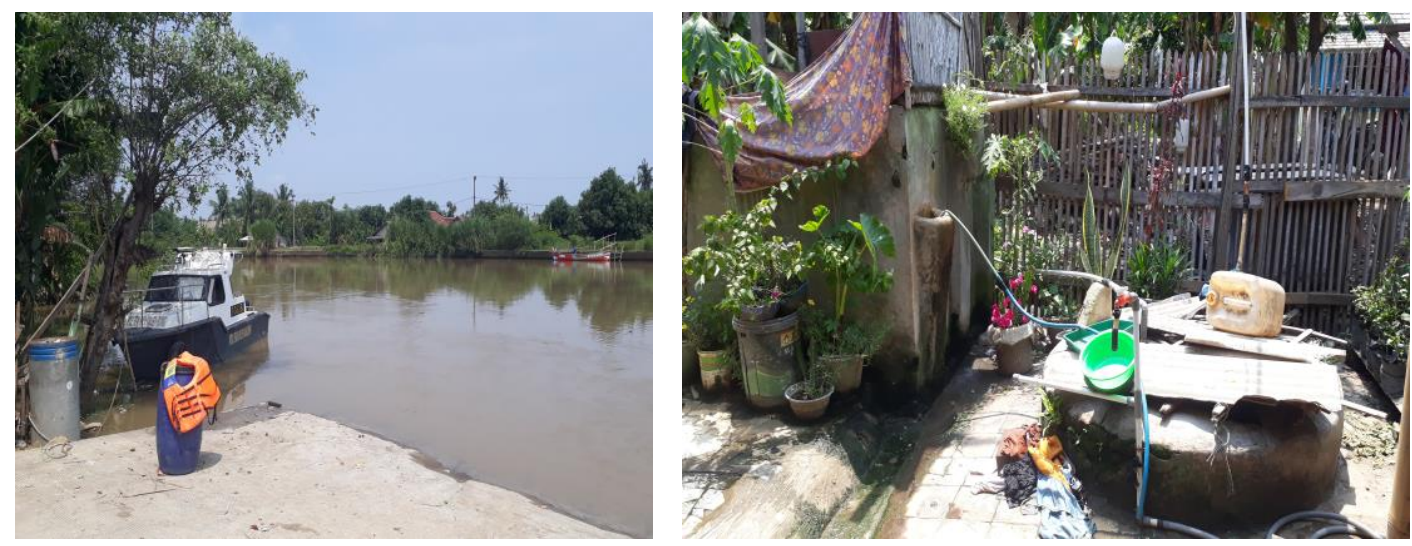

Sumber: Hasil Pelaksanaan (2021)

Gambar 4. Gambar Perikiraan Lokasi

\subsection{Focus Group Discussion}

Data-data yang terkumpul dari hasil survey selanjutnya ditindaklanjut dengan kegiatan Focus Group Discussion, narasumber yang dilibatkan adalah penggiat pariwisata, aparatur pemerintah dari Kecamatan Muara Gembong. FGD dilaksanakan untuk mendapatkan masukamasukan mengenai langkah-langkah yang dapat dilakukan untuk mengangkat potensi pariwisata di wilayah mereka, Tentunya dalam kegiatan ini tim berusaha untuk memfokuskan arah diskusi untuk mendapatkan gambaran kebutuhan yang relevan dengan racangan waktu dan anggaran kegiatan.
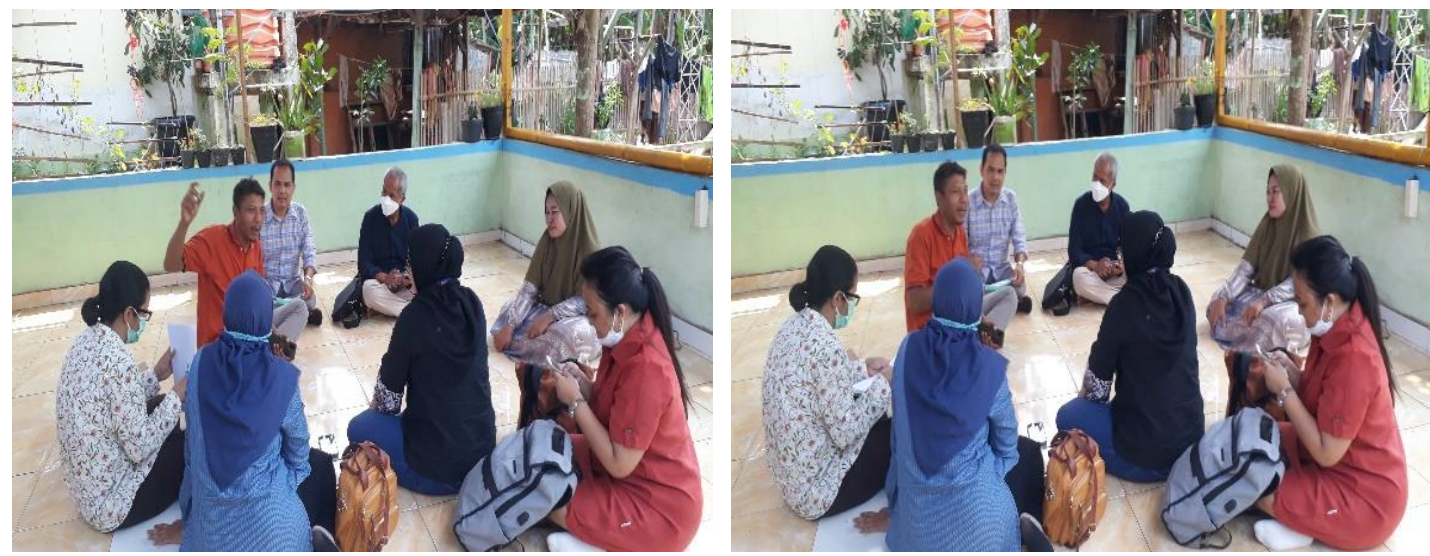

Sumber: Hasil Pelaksanaan (2021)

Gambar 5. Pelaksanaan Diskusi dengan Warga 
Erik Saut H Hutahaean, Dhian Tyas Untari, Soehardi, Tulus Sukreni, Timorora Sandha Perdhana, Fata Nidaul Khasanah, Iskandar Zulkarnaen, Djuni Thamrin

\subsection{Susunan Program}

Hasil diskusi dijadikan dasar oleh tim untuk menyusun program kegiatan. Dari sejumlah kebutuhan yang berhasil diungkap tim mendapatkan salah satu tema yang cukup relevan dengan upaya meningkatkan potensi wisata melalui pembangunan prasarana pendukung berupa MCK atau toilet (termasuk instalasinya) yang dapat dimanfaatkan oleh warga masyarakat dan juga dapat digunakan oleh wisatawan. Dalam penyusunan program termasuk juga penentuan lokasi strategis untuk menempatkan MCK portable.
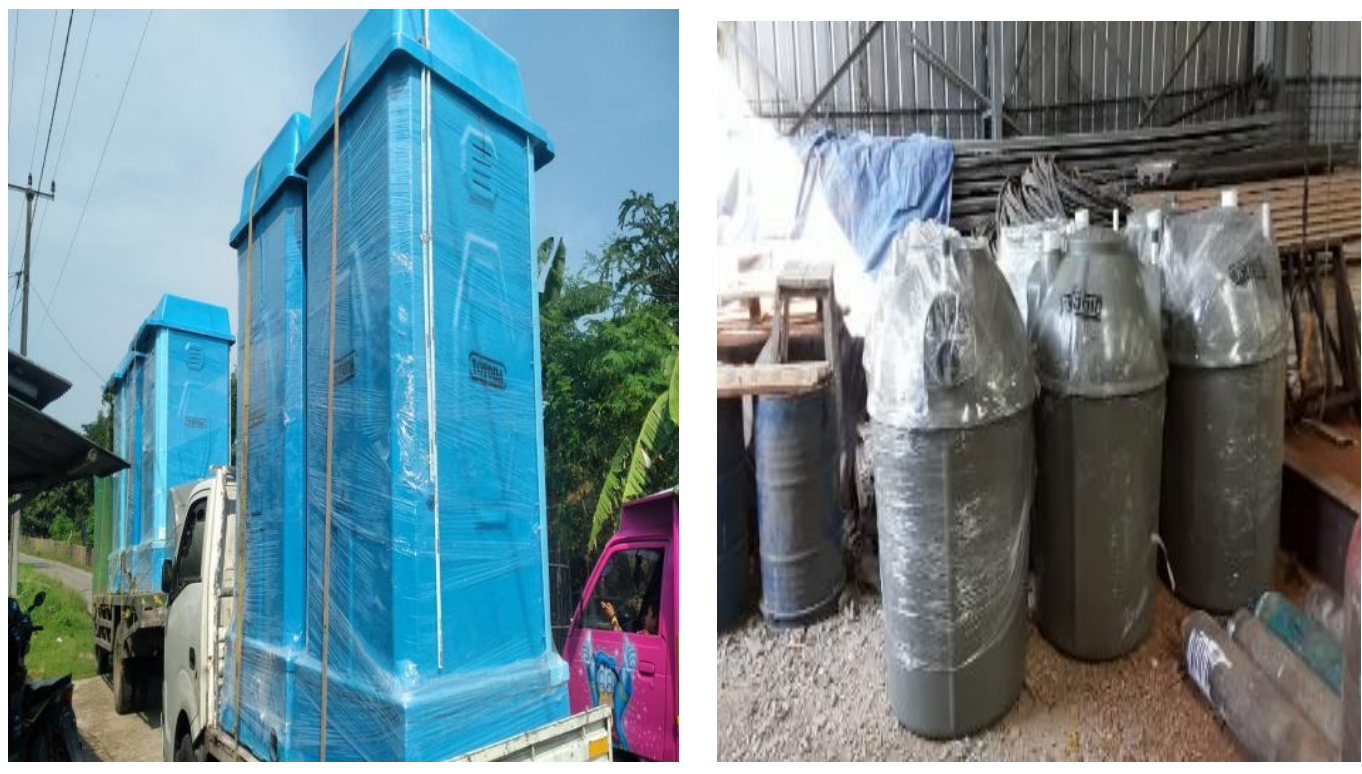

Sumber: Hasil Pelaksanaan (2021)

Gambar 6. Gambar Rancangan MCK

\subsection{Penentuan Titik}

Penentuan titik didasarkan kepada area-area yang dinilai cukup strategis, dengan pertimbangan merupakan lokasi yang sering dijadikan tempat transit wisatawan untuk melaksanakan perjalanan wisatantnya. Adapun titik yang dimaksud adalah tempat berkumpul yang berada disekitaran komplek Yayasan Nurul Jannah, gerbang dermaga yang berada di depan kantor kecamatan, dan area sekitaran sekolah MTS yang berada di kampung Blukbuk Desa Pantai Bahagia. Titik pemasangan gerbang dermaga depan kantor kecamatan merupakan pemasangan baru, sementara dua titik lainnya adalah menggantikan toilet yang sudah sangat tidak layak.

Tabel 1. Titik Penentuan Lokasi

\begin{tabular}{lll|l|}
\hline Titik & Lokasi & \multicolumn{2}{l}{ Keadaan Setelah } \\
\hline 1 & Dermaga depan kecamatan & & \\
& & & \\
& & & \\
& &
\end{tabular}




\begin{tabular}{llll}
\hline Titik Lokasi & Lingkungan sekitaran MI Nurul Jannah \\
\hline 2 & &
\end{tabular}

Sumber: Hasil Pelaksanaan (2021)

\subsection{Pemesanan Unit MCK Portabel}

Hasil dari diskusi mendapatkan adanya kebutuhan prasarana umum, berupa MCK atau toilet. Dalam hal ini tim abdimas mencoba untuk menyesuaikannya dengan ketesediaan waktu pelaksanaan dan penganggarannya. Sehingga unit yang dipilih berupa MCK/ toilet portable. Mengingat proses pengerjaan dan pembuatan instalasinya membutuhkan waktu yang relatif singkat.
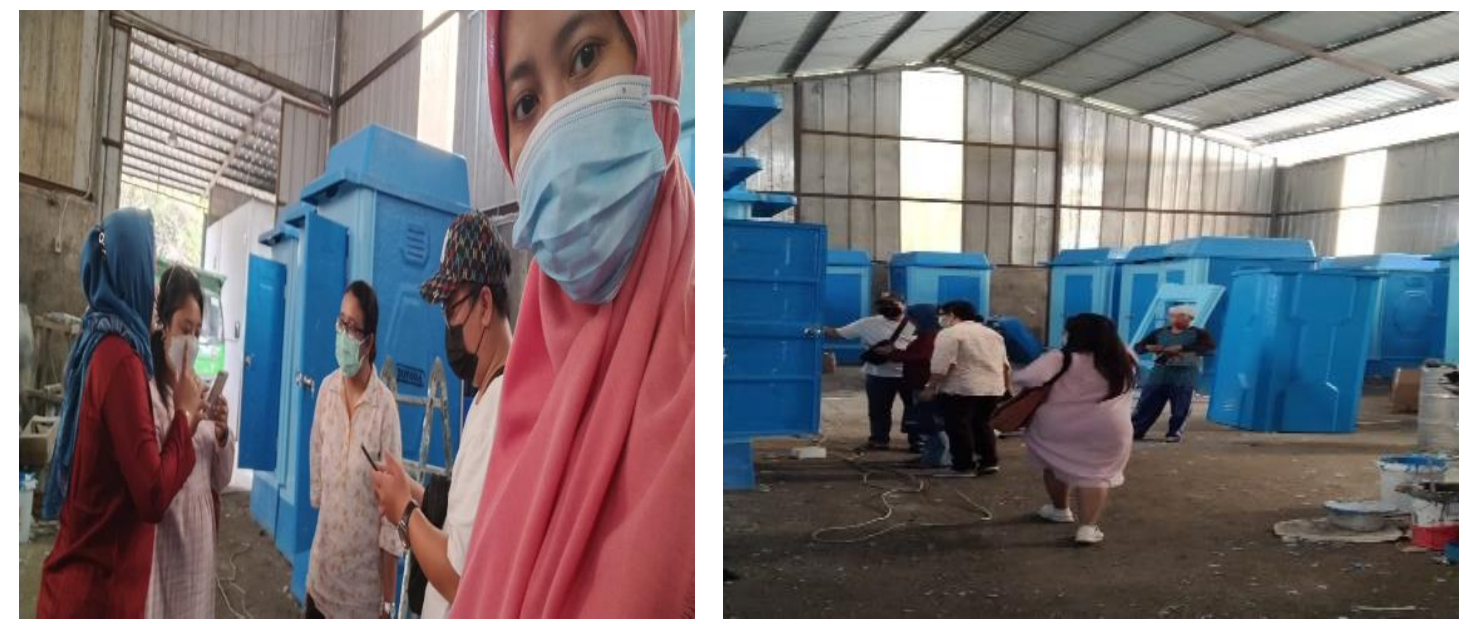

Sumber: Hasil Pelaksanaan (2021)

Gambar 7. Survey dan Pemesanan MCK/Toilet 
Erik Saut H Hutahaean, Dhian Tyas Untari, Soehardi, Tulus Sukreni, Timorora Sandha Perdhana, Fata Nidaul Khasanah, Iskandar Zulkarnaen, Djuni Thamrin

\subsection{Pemasangan Unit}

Konsep pemasangan unit MCK portable dilaksanakan bersamaan dengan pemasangan instalasi pendukungnya. Seperti septick tank dan instalasi air. Pemasangan unit dilakukan dengan dibantu oleh masyarakat sekitar, yang pemantauannya dibantu oleh kelompok masyarakat penggiat pariwisata Kecamatan Muara Gembong. Pemasangan berlangsung selama dua hari.

Tabel 2. Pemasangan Unit MCK/Toilet

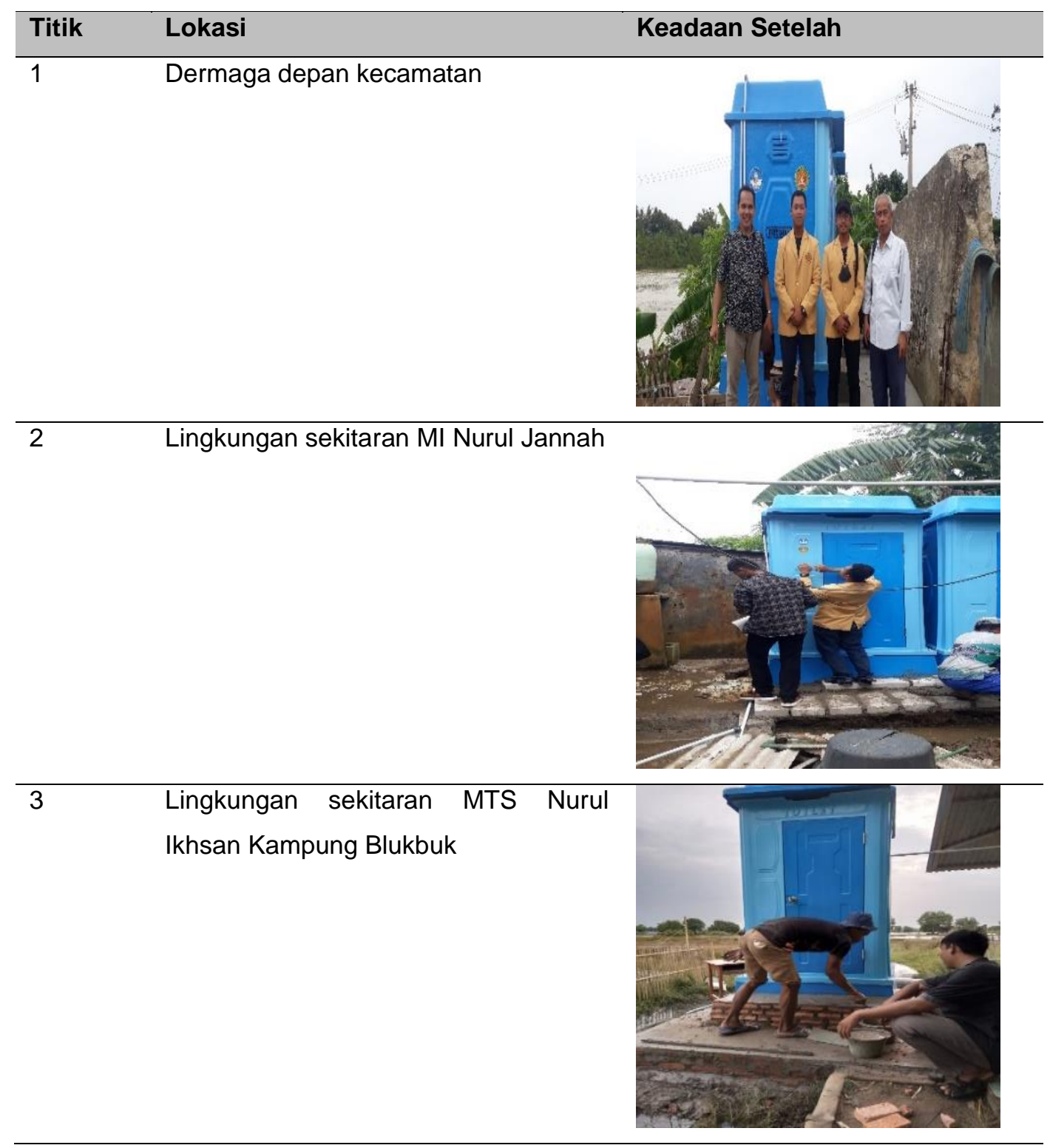

Sumber: Hasil Pelaksanaan (2021)

\subsection{Serah Terima}

Dalam waktu dua hari, setelah unit sampai dilokasi. Timabdimas kemudian berkoordinasi dengan warga untuk dapat turut serta dalam kegiatan pemasangan unit MCK atau tolilet portable. Kemudian diadakan kegiatan penyerahan secara simbolis oleh tim 
Abdimas Universitas Bhayangkara Jakarta Raya kepada perwakilan masyarakat penggiat pariwisata.

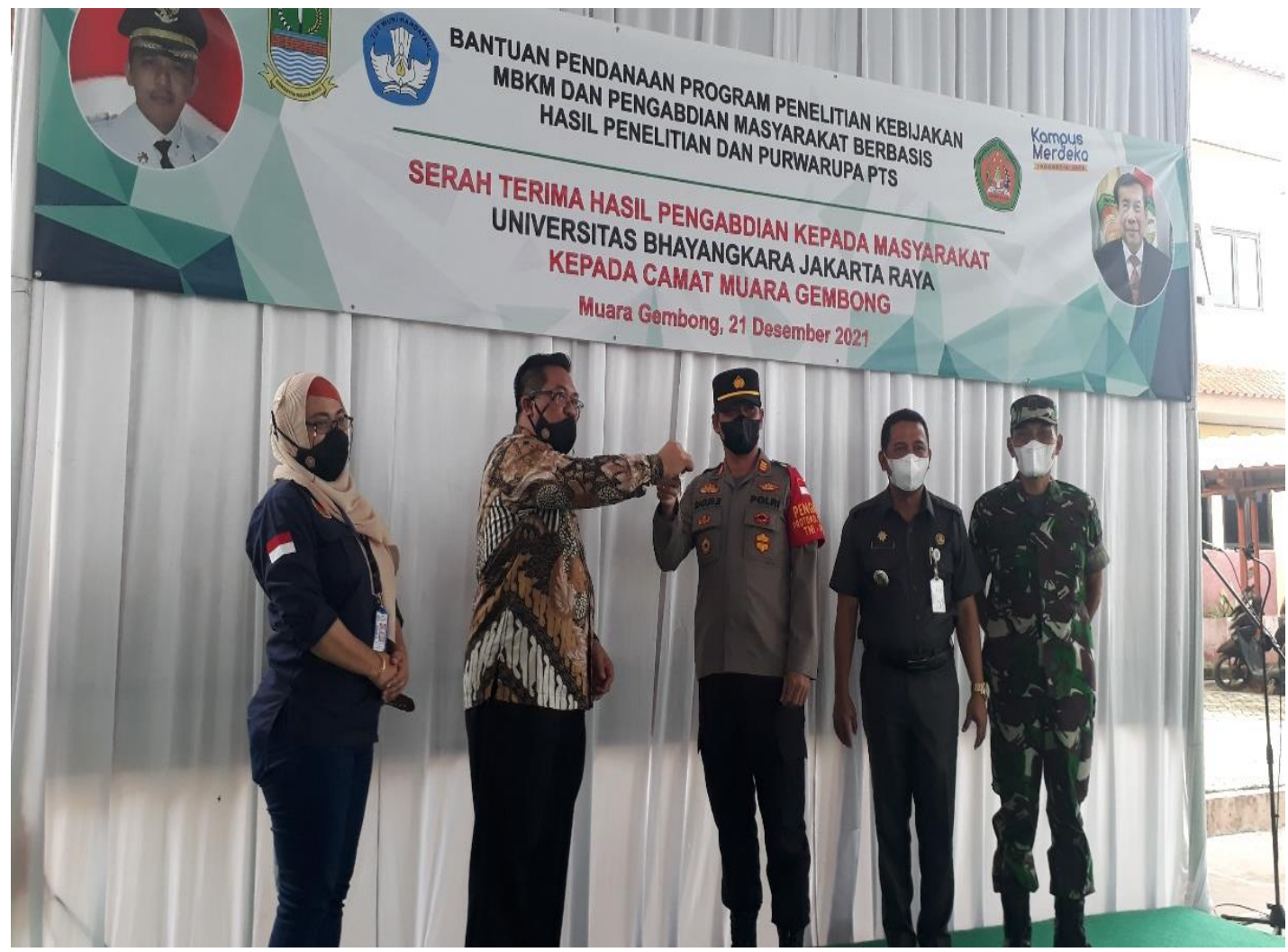

Sumber: Hasil Pelaksanaan (2021)

Gambar 8. Serah Terima Hasil Pembangunan MCK/Toilet

Secara simbolis serah terima dilakukan di depan lingkungan kantor Kecamatan Muara Gembong, dalam kegiatan ini dilakukan secara seremoni berupa penyerahan kunci MCK/toilet dari perwakilan Universitas kepada perwakilan dari pihak Kepolisian, untuk kemudian diserahkan kepada masyarakat penggiat pariwisata.

\subsection{Seminar Hasil}

Kegiatan seminar hasil dilakukan dngan melibatkan pengulas dari masyarakat penggiat wisata, masyarakat kecamatan muara gembong, dan kalangan akadmisi. Kegiatan ini dilakukan dengan mekansime tim abdimas melakukan pemaparan hasil yang sudah dilaksanakan terkait pelaksanaan program pengabdian kepada masyarakat tentang pendampingan mengangkat potensi pariwisata di Kecamatan Muara Gembong. Dalam kegiatan seminar hasil juga dilakukan kegiatan kegiatan diskusi, dimana pada sesi tersebut pihak mitra diminta untuk memaparkan kebermanfaatan yang dirasakan langsung oleh mitra terkait dengan program pengabdian kepada masyarakat yang telah dilakukan oleh tim. 


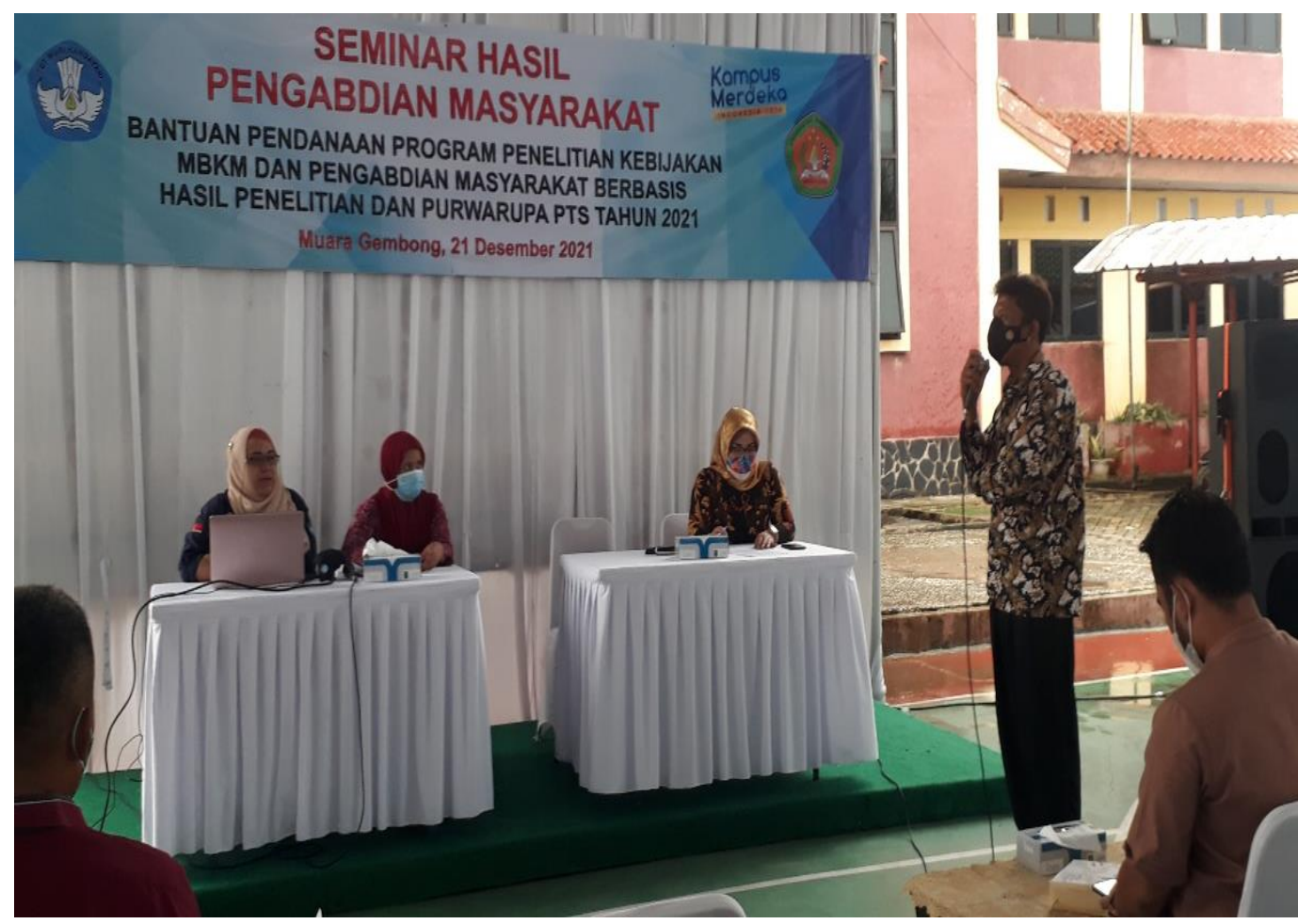

Sumber: Hasil Pelaksanaan (2021)

Gambar 9. Narasumber Pengulas Bertanya Saat Seminar Hasil

\section{Hasil dan Pembahasan}

Porgram yang diracang dalam kegiatan abdimas di Kecamatan Muara gembong dikhususkan kepada upaya pendampingan yang dapat membantu terbentuknya keberdayaan yang mandiri dari masyarakat dalam mengangkat potensi pariwisata. Kebutuhan MCK/toilet menjadi sesuatu yang tidak bisa ditawar, meskipun terkesan sederhana ternyata toilet menjadi salah satu indikator yang cukup relevan dengan kepuasan dalam sektor pariwisata. Pembangunan toilet yang dilakukan di lingkungan kecamatan muara gembong dipandang oleh masyarakat sudah ditempatkan pada lokasi-lokasi yang memang sangat bisa digunakan oleh masyarakat banyak, dalam hal ini warga dan wisatawan.

Pembangunan MCK/toilet mendapatkan tanggapan yang positif bagi masyarakat, karena dianggap sebagai langkah yang paling nyata. Prasarana yang dibangun langsung dapat dimanfaatkan oleh masyarakat. Misalnya yang berada di dermaga depan kantor Kecamatan, karena sebelumnya wisatawan yang hendak berwisata sangat sulit untuk bisa mendapatkan toilet sesuai keperluannya. Sama halnya dengan toilet yang dibangun di lingkungan MI Nurul Jannah, dapat langsung digunakan oleh warga sekiatar, belum lagi lokasi ini merupakan titik transit berkumpul orang-orang yang hendak melakukan wisata peminatan memancing. Sedangkan untuk satu titiknya dapat langsung digunakan oleh warga sekitaran lingkungan kampung Blukbuk, belum lagi lokasi ini berada pada lokasi wisata pantai Bahagia.

Pembangunan MCK/toilet ini juga memberikan manfaat mengenai kehidupan yang sehat bagi masyarakat sekitarnya. Sehingga lingkungan dapat diminimalkan pencemarannya, 
dan masyarakat pengguna dapat memanfaatkannya untuk kebersihan badannya. Citra lingkungan dan masyarakat yang bersih juga akan dapat terangkat melalui pembangunan MCK/toilet.

\section{Kesimpulan}

Dalam hal berupaya membangun potensi wisata memang memerlukan penggalian beberapa indikator yang dapat membantu untuk mempromosikannya, yang dalam hal ini adalah melalui prasarana MCK/toilet. Sebagai wujud nyata (meskipun terkadang dianggap sepele) MCK/toilet menjadi salah satu indikator yang dapat menjad bagian pendukung dalam mengangkat potensi wisata. Tidak hanya pengunjung yang berwisata, masyarakatpun dapat merasakan kebermanfaatannya. Namun demikian kebermanfaatan program ini masih memerlukan dukungan masyarakat agar dapat terus berlanjut, melalui mekanisme pengelolaan kebersihannya dan perawatannya. Mengingat untuk benar-benar dapat mengangkat seutuhnya potensi wisata merupakan membutuhkan suatu program jangka panjang.

\section{Ucapan Terima Kasih (Opsional)}

Terima kasih kami ucapkan kepada Kementerian Pendidikan, Kebudayaan, Riset, dan Teknologi yang telah membiayai terlaksananya kegiatan pengabdian kepada masyarakat dalam bentuk "Program Bantuan Pendanaan Program Penelitian Kebijakan Merdeka Belajar Kampus Merdeka dan Pengabdian Mayarakat Berbasis Hasil Penelitian dan Purwarupa" Tahun Anggaran 2021. Selain itu, terima kasih kami ucapkan kepada Universitas Bhayangkara Jakarta Raya yang telah mendukung dan memfasilitasi pelaksanaan kegiatan pengabdian kepada masyarakat. Kami ucapkan banyak terima kasih juga kepada Kelompok Sadar Wisata daerah Muara Gembong yang selaku mitra kegiatan pengabdian kepada masyarakat.

\section{Daftar Pustaka}

Alfiah, A., Andriani, J., \& Furyanah, A. (2020). Efektifitas Pengelolaan Lokasi Wisata Curug dan Bukit di Subang Jawa Barat. Jurnal Pemasaran Kompetitif, 3(2), 68. https://doi.org/10.32493/jpkpk.v3i2.4309

Asyiawati, Y., \& Akliyah, L. S. (2011). Identifikasi Dampak Perubahan Fungsi. Jurnal Perencanaan Wilayah Dan Kota, 14(1), 1-13.

BPS Kabupaten Bekasi. (2020). Kabupaten bekasi dalam angka (Bekasi Regency in Figure) 2020. 223.

Daniswara. (2021). Abrasi di Desa Pantai Bahagia Kecamatan Muara Gembong Kabupaten Bekasi. Kompasiana.

Deswati, R. H., \& Luhur, E. S. (2014). Profil budidaya dan kelembagaan pemasaran rumput laut (grasillaria sp) di kecamatan muara gembong, kabupaten bekasi, jawa barat. Buletin IImiah Marina Sosial Ekonomi Kelautan Dan Perikanan, 9(1), 31. https://doi.org/10.15578/marina.v9i1.231 
Erik Saut H Hutahaean, Dhian Tyas Untari, Soehardi, Tulus Sukreni, Timorora Sandha Perdhana, Fata Nidaul Khasanah, Iskandar Zulkarnaen, Djuni Thamrin

Jabarprov.go.id. (2017). Potensi Daerah Pariwisata.

Susetyarini, O., \& Jussac Maulana, M. (2011). Pengukuran Tingkat Kepuasan Wisatawan Terhadap Fasilitas. Jurnal Kepariwisataan, 6(January).

Widyanti, N. L. S., Anggreni, M. A., Sumardiana, I. N. J., Yasti, H., \& Kurniansah, R. (2020). Manajemen Pengelolaan Toilet Umum Di Daya Tarik Wisata Kuta Lombok Tengah. Jurnal Inovasi Penelitian, 1(1), 1-6. https://doi.org/10.47492/jip.v1i1.39 